RALPH LEVINSON

\title{
CH\#. I KNOW WHAT I WANT TO TEACH BUT HOW CAN I KNOW WHAT THEY ARE GOING TO LEARN?
}

\author{
Creative Science Teaching: An Uncertain, Emancipatory And \\ Perturbing Endeavour
}

\section{THE CRITICAL ISSUE}

Those advocating science for social justice pedagogy within school curricula face political, economic and educational challenges in the face of $\mathrm{STEM}^{1}$, (Science, Technology, Engineering, Mathematics) education. This acronym -almost an ideology so quickly and so deeply has it pervaded educational discourse and become synonymous with 'science' -has crept up stealthily on the world of science education, accompanied by terms such as 'innovation', 'competitiveness', 'entrepreneurship', 'enterprise' and 'excellence' (The Royal Society, 2009). It points to a move in science and technology education to liaise more closely with business and private enterprise than with the public and state sectors. STEM education proponents make particular claims for human capital to support technological innovation in a consumerist society, as evidence, for example, by encouraging STEM careers in science lessons (Hutchinson, 2012) and is itself a science-society formulation; hence, it melds very well into calls to link the study of science more closely to social concerns (Gough, 2015). Implicit, too, in the term STEM is inter-disciplinarity. U.S. schools and UK schools need to emphasize a STEM epistemology to justify its social and economic existence and the ways in which science can support technology and engineering, although little work on pedagogic and curricular integration has been done in this direction. But the motivations of STEM are economic and corporatist. They are also political because the question arises as to whose benefits such changes are directed (Owen et al., 2009).

Extracts from the foreword to The Royal Society's (2009) report Hidden Wealth exemplify these purposes:

How has science contributed to this growth of wealth and enhanced quality of life via services?

... we set out to answer a simple question: where has science-in the widest sense-already contributed well to fostering innovation in the services sector and where and how might new policies enhance the situation? 
We anticipate services delivered much more cheaply, to better quality and personalised to millions of individuals where that is desired. While much of this will be provided by the private sector, government can enhance its own services hugely by cloning the best of private sector developments to maximise value for taxpayers' money and to strengthen democracy...

Ever better collaboration between STEM practitioners and social scientists and those in the humanities will be essential if the services are to be acceptable and fit for purpose. Changes in our educational system would also make a material contribution to such success. (p. v).

STEM has now become a clarion call in the push for national economic competitiveness. Drives towards more STEM education for the labour market have become a cornerstone of EU policy (Caprile et al., 2015). Wealthy economies which fail to reach the heights of the Programme for International Student Assessment (PISA) scores of the powerful East Asian economies resort to introspection and 'standards speak', demands for more content-laden delivery of the curriculum and improved assessment scores. The UK opposition spokesperson on education pointed to "... the importance that these [Pacific rim] high-performing education systems place on the quality and status of the teaching profession as the central lever for driving up standards" (Adams, 2013). The UK education minister at the time, Michael Gove, forefronted his Parliamentary statement in response to PISA 2013 scores with a drive towards social justice, dressed in the language of increased marketisation of the education sector and a call for greater accountability and performance. TheTelegraph, a centre-right newspaper reported that government reforms to the curriculum will "scrap 'vague', non-scientific topics such as caring for animals and societal context" (Dominiczak, 2013).

Despite the recruitment drive for the STEM corporate market, national attitudes towards science among young people stand in inverse relationship to national GDPs (Rose, 1998). Scandinavia and Japan score the lowest for young people's positive attitudes towards science (Schreiner \& Sjøberg, 2007) while Uganda top the list. The writings among socialists in 1930s Britain (Bernal, 1969) seeking to overturn the excesses of capitalism through increased knowledge of, and engagement in, science stand in a curiously inverse relationship to contemporary policies: one links increased understanding of science to liberation from the shackles of capitalism, the other focuses on rigour to compete in the global market.

The neoliberal assault on school education over the last twenty years has affected teaching and the curriculum as well as school organisation, with a school culture focused on short-term outcomes driven by examination results (Hargreaves \& Shirley, 2009), pedagogic conformism and performativity generated through new technologies of control, so that teachers become "fabricated", changing their identity to represent the performative culture of the organisation for appraisal (Ball, 2003).

While globalisation and neoliberalism, and the concomitant drive towards cultural homogeneity, are the dominant economic factors prevalent in STEM, there are local and historical differences which constrain what is possible, and the perspectives through which teachers, school policy makers and students 
come to these issues: in the UK, for example, the influence of science for the worker since the industrial revolution (Layton, 1973), the relationship of academic subjects to vocational subjects (quite different from the situation in Germany) (Osborne \& Dillon 2008), and the influence of a liberal education distinguish the challenges facing science education in the UK compared with other countries. What might be appropriate pedagogical shifts in response to STEM in one country might not apply to another despite globalisation.

In addressing what I see as the subjugation of science teaching to the consumer market, I want to turn the narrative to an emphasis on epistemology and creative science teaching before coming back to some cautious suggestions to transform the present situation.

\section{What Science Might Mean to a Young Person}

When I was 16 , I had an epiphany - in a secular sense. One afternoon when I was not focusing on anything in particular it struck me, as if lightning had flashed out of an unlikely sky, that the ideas of atomic chemistry were aweinspiring. Here was a world of atoms, protons, electrons, spin, orbitals which explained so much; non-perceptible, real yet entirely the product of human thought and social practise. I felt just at that moment how ineffably joyful and possible- the world is, a sensibility that has never quite left me. Until that point, I had been using my school notes and textbooks to solve chemistry problems but had never imagined, let alone understood, what existential processes were at stake. DNA, continental drift, neurobiology, nuclear physics now became both real and mind-boggling.

Over the years, there appeared to me to be a link between this experience and a commonality among creation stories whatever their sources - JudaeoChristian, Maori, Hindu - the shift from darkness to light (or in pedagogic terms, illumination), formlessness to structure, in other words, an ontological transformation. (Although I regard myself as completely secular I feel the Old Testament depiction of Creation as the shift from 'tohu vavohu' (formlessness) to the illumination of being (God said 'Let there be light') is more meaningful for the scientific sense of creativity than the ideas of innovation, novelty and value (Kind \& Kind, 2007) or through cognitive strategies (Mayer, 1989).)

The world was different after my epiphany: it was patterned. It had become describable and hence explicable. This presupposed certain characteristics that gradually became explicit. In the words of Richard Rorty (1989), "The world does not speak. Only we do" (p. 6). The conceptualisation of Nature as explicable through the mediation of human consciousness, therefore sociocultural - as opposed to supernatural intervention as in creation myths - seems to me to be such a crucial point in justifying science on the curriculum that it issurprising that it is at best implicit - I see a distinction here between the experience I describe which is integral to what it is to be human from concept change theory (Strike \& Posner, 1982). The latter seeks to explain how young people's concepts might change without necessarily taking into account the personal meanings associated with such changes. Its immediacy was brought home to me recently through reading a poem of Wallace Stevens, The Idea of Order in Key West, which speaks to the nature of reality (Kermode \& Richardson, 1997). In this poem, Stevens is 
relating to a friend of his feelings on hearing a woman singing by the seashore. The woman's voice conveys the sound of the sea which brings to the fore the mediation of human interactions in our perceptions of the world.

The song and water were not medleyed sound

Even if what she sang was what she heard,

Since what she sang was uttered word by word.

It may be that in all her phrases stirred

The grinding water and the gasping wind;

But it was she and not the sea we heard. (pp. 105-106)

My reading of the poem is that the rhythm, patterning and mythical resonances of the sound of the sea do not reach our consciousness directly but are mediated through the voice and consciousnesses of others. Meaning, saturated with cultural and emotional resonance, emerges through human discourse in its most general sense. Yet that meaning, the form and structures, which seem so compellingly real - the Periodic Table, structure of DNA, habitat interrelationships, mechanisms of energy transfer - is inherently unstable because humans continue to argue and interpret Nature and upset the paradigms to which we become so habituated (Kuhn, 1970). The uncertainty between 'what is' - the canon of school science - and 'what might be' is at the core of human possibility.

\section{The Role of Pedagogy}

So how might teaching support these kinds of transformations even in the context of contemporary science education?

Underpinning my view of the environment necessary for creative teaching challenging the hegemony of STEM - and hence transformative understanding, arose from an incident about ten years ago. It was in a debriefing meeting I had in my role as a teacher educator with a pre-service teacher, Tom, a thoughtful and knowledgeable science graduate.

When I came to observe Tom teach a Year 10 group (14-15 year olds), I was met before the lesson by his school mentor, Judy, who told me that she had serious concerns about his progress and that "in all likelihood teaching isn't for him." Since his planning for lessons was unusually meticulous as I had seen through the materials he prepared and a narrative he practised at the beginning of each week, I was taken aback. There was little time before the lesson so we agreed to talk about his progress after it. The episode I saw him teach was based on a question: "How can we know what's inside the Earth?" He began with a poem about an earthquake and had a number of models set around the room, which the students had to interrogate in terms of their plausibility as explanatory structures. As they did this, he encouraged the students to articulate two things: first was the difference between their understanding of the earth's structure and inner composition and what the models were portraying; and secondly anything they could say about the validity of the models, i.e. what they represented. He had mistimed the lesson (not uncommon among beginning teachers). It ended rather earlier than he had planned but not before students were expressing their surprise at the differences between their own representations of the Earth's structure and the models, as well as curiosity as to how models come to be constructed. I overheard a comment from one student to his friend as he left the lesson: "It makes you wonder, man. I thought it was all solid rock down there." At least 
this student's transformed understandings of this aspect of Nature seemed to reflect my own epiphany many years before.

After the lesson, Judy, who had supported many of our student teachers and with whom I had a good professional relationship, asked me if I could now see the problem. I was baffled. After I had a moment to recover, I asked what her concerns were. "The lesson outcomes and objectives. Where were they? And what about the starter, the middle and the plenary?" At this time in England there was a National Strategy advising that all lessons should have, or rather conform to, a three-part structure.

Judy was a mentor whose judgement I had always trusted, but I realised that if she was undergoing this process of fabrication we were in trouble. When I debriefed with Tom, I asked him why he hadn't put the learning objectives to the class at the beginning of the lesson and why they weren't on his plan. Lesson outcomes and objectives go on the planning sheet and I took it as commonsensical that these were part of the tools of lesson planning. After a moment's thought, peering at me ingenuously, he responded: "I know what I am going to teach. But how can I know what they are going to learn?" It took me some time to understand the power of this observation. It was not simply about learning a few propositions such as "the Earth is made up of different layers" but what meaning students made of them. In many ways, I was as fabricated through working to imposed teacher standards as Judy, the teaching mentor.

What Tom was doing was encouraging the students to think about what is known about the Earth's structure, how we come to know this given the provisionality of scientific knowledge, and what it means. He had a deep knowledge of the topic, hence his care in selecting appropriate models and his ability to gently present students with counter-factuals when they made assertions. But he always left the door open for them to come back with further justifications for their own conclusions, nor would he impose the accepted right answer. The students, first implicitly, then explicitly, were coming to appreciate that Nature as represented wasn't 'given': reason, affect, inference and knowledge came to temper the 'rough ground' (Dunne, 1993).

When I was reading Hannah Arendt's The Human Condition, inspired by Joseph Dunne's book Back to the Rough Ground, I began to see the pedagogic importance of what Tom had taught me and what had taken me some time to assimilate. The Human Condition was written after the Second World War and among its many messages is a reflection on the nature of tyranny. Arendt distinguishes between two forms of reasoning: techne and phronesis.

Techne is associated with purposive reasoning encompassing activities (called poiesis), which have formulated ends, where technical proficiency leads to predefined outcomes. Poiesis is not necessarily a mindless process; it involves a mastery of certain techniques. It is craft with a rationality underpinning it. This has some relation to what is meant in contemporary language by technicism or technicist, the rationale is a means to a specified end. It is to operationalise, to concretise something that is given, e.g. a learning outcome. So a teacher who prescribes a learning objective and directs their teaching to meeting that particular given objective is in a sense technicist, and in standard terms a very good teacher. The idea is prescribed from somewhere beyond the person and their job is to implement it fully. The choice of what is prescribed is not theirs; 
hence techne was something looked on askance by the free citizen in the Greece of Aristotle.

Praxis, as distinct from poiesis, is a realisation of one's self, one's inner worth, a mediation of the social and individual, and indicates less control over a means-end relationship over which you had complete sovereignty, a more personal and experiential knowledge. Associated with praxis are contingency, uncertainty and heterogeneity, quite distinct from the more circumscribed practise of poiesis. This practical knowledge or wisdom is phronesis, and although non-technical has an underpinning rationality. Arendt expands the notion of praxis in relation to 'action' as opposed to 'making'. To take action is to put one's ideas to the judgments of others where one ceases to be the actor - it is to acknowledge uncertainty and change and accept the limits of control. Human agency, which underpins praxis, is deemed to incorporate distinctiveness and equality. Distinctiveness presupposes speech and action because these relay the agent's need to reveal who they are and make themselves understood. Equality is the condition for mutual understanding, hence recognition for the past and an ability to co-operate in planning for the future.

\section{$<$ Figure 1 here >}

The rationale behind modern theories of praxis, derived from both Hegel and Marx, is the realisation of consciousness through action

Embedded within a tradition of communally shared understandings and values, that remain vitally connected to peoples' life-experience, that finds expression in their ordinary linguistic usage, and that, rather than being a means through which they achieve outcomes separate from themselves, is a kind of enactment through which they constitute themselves as persons in a historical community. It is through praxis that a person comes to have an individual identity, but at the same time it always transpires within an intersubjective medium. . . The moral subject, the subject of praxis, is inconceivable in abstraction from communicative relations with others. (McCarthy, 1978, p. 35).

So the relationship between knowledge and action is turned the other way around, that is in a Deweyan sense, knowledge is accrued through collaborative inquiry in acting upon the world (Tobin, 2014). Action becomes an existential choice which becomes more challenging in a world saturated with discourses promoting a uniformity of consumption.

This is the first distinction I want to illustrate using this example, that Tom understood something about the ways young people might conceptualise reality and that he could not reify any meaning when confronted with something which challenged their prior representations. So Tom could have specified certain concepts for students to explain, such as the Earth's structure is made up of $\mathrm{x}$ layers. Instead his approach was to lay out the problem as best he could, indicating the strength and tentativeness of what was and what was not known, and allow students to interpret this knowledge in their multiplicity of ways. 
The post-Enlightenment relationship of the Self to the Other is one that has human subjectivity (the Self) imposing order and meaning on Nature (the Other). The project of modern science is intrinsically connected with power and domination:

From its Baconian inception, modern science has been about both knowledge and power, above all the power to control and dominate nature, including human nature. Nowhere perhaps has this Faustian pact been made so explicit as in the programme that has shaped molecular biology since its origins. (Rose, 1998, p.273)

For the philosopher Emmanuel Levinas (1993) ethics begins with the realisation of the Other, that the Self is constituted by and responsible for the Other by opening oneself to the Other non-reciprocally, (the Other has no ethical responsibility towards me, i.e. the Self), consequently the possibility of social justice. In Western philosophy the Other is appropriated as part of the same and loses its alterity. Ann Chinnery (2000), drawing on Levinas, exposes the problem of neglect of the Other even when people act altruistically towards other human beings in the name of common humanity. This advocacy of sameness, of commonality - "they are after all, one of us" - can also impel people to act barbarously towards human beings because they do not see them as the same. In other words one's moral obligations are perceived to extend only to those for whom there is a perceived sameness. For Levinas, there is no pre-ethical subject: the lesson for education is moral responsibility, for the other lies outside familial or even species relationship, and the Self becomes realisable through the acceptance of the Other.

This refusal to impose one's subjectivity, the acceptance of the Other, the notion that we always have a responsibility for the Other, has consequences for pedagogy. An everyday example is the difference between the question "Would you like to come into my home?" and "Welcome to my house". The first asserts a subjectivity; it puts the onus of the guest to accept my invitation. The second is an opening up without any pre-conditions. The teacher must welcome difference in terms of the voice of the students and the Otherness of the natural world, both biotic and abiotic. All actions taken on the world must take into account the needs of others, the sharing of the world (Blades, 2006). To impose learning objectives is not to see the otherness of the student, it is to stamp one's own subjectivity on to another. To see students as the Other is to open oneself up to them, where teachers become learners and students as a consequence become teachers as well as learners. This is not to imply a freefor-all, however. As in the case with Tom, the teacher steers a course between inducting the students towards a problem (Le Dit) and the "Saying" (Le Dire). David Blades (2006) refers to the "Saying" as "an invocation to the rupture of my being" (p. 658). Hence, the Other - organisms, their interactions, the students growing knowledge of these interactions - is not a phenomenological construct but is allowed to rupture the experiential world of the subject.

In contemplating the relation of the presence of the Other to Nature, Blades (2006) draws on the notion of a pond. (Levinas did not include non-humans in his call to the Other but others, e.g. Llewellyn (1991) and Blades (2006) have expanded on his philosophy towards the non-human world.).A pond has no 
definable boundaries: the water from the pond overlaps surrounding mud and vegetation, oxygen from the atmosphere slowly dissolves in the water as surface water molecules evaporate into the atmosphere and condense back into liquid water. The call of the frogs from the pond has diminished over the years. But there is a difference between nature in flux - through Natural Selection species come and go - and the responsibility to the Other. One could imagine Nature without humans which then brings starkly forward human responsibility. What would the pond be like without human interference? Might local human-made pollutants be responsible for changing the pond or might it be the relentless change of Nature? We have a responsibility to respect the latter and not to act or, if necessary, to act. Imagination and sensitivity to the Other mediates the choices.

Teaching like Tom's episode bring the same ethics to their students as they do in their feelings of responsibility towards Nature, non-presumptiveness: a refusal to dominate which accompanies a liberation of the scientific imagination.

\section{The Dawning of Uncertainty}

Until now I have dwelt on the point that creative teaching - that which promotes ontological and with it epistemic transformations - sits uneasily with the ways in which neoliberal education systems are run. I want to add a further dimension through the illustration of another teaching episode to further this characterisation of creative teaching and the circumstances in which it might flourish.

John was another student teacher who had completed the course a year or so before Tom. Unlike Tom's school, John's practise was in a school where he had some freedom to make mistakes, and was encouraged to take risks. The lesson I saw him teach was to 11-year-olds about graphing the rise in temperature of water against time, which on the surface looked as bland a lesson as one could possibly imagine. John had shown the students how to read thermometers correctly, to take measurements and to plot a graph. The students were then asked to draw a temperature time graph, heating the water and taking the temperature every 30 seconds until they were confident there was no further rise in temperature. After they had done this he drew their attention to the fact that there were two different types of graph drawn by the students (Figures 2 and Figure 3). In Figure 2, students had drawn a best-fit graph based on their previous knowledge of what happened when water boiled, whereas the others had joined the points together. Without any obvious direction towards a "right" answer John asked the students to talk about the graphs they had drawn. The students who had joined up the data points regardless asked the other students why they hadn't joined up the points. At this juncture the students said they just knew 'that's how the graph should go'. This then led to a discussion of the reliability of data, that all measurements of temperature were prone to error: human error, the constraints of the measuring instrument, and the problem of outliers. How could you know whether a measurement was the right one? So John put the question back to them: how could they know the boiling point was 100C? Gradually the students began to realise that no measurements could give certain knowledge and that how you drew the graph was theoretically constrained, drawing on previous knowledge. There was a slight perturbation because they had always accepted as a mantra that water boiled at $100 \mathrm{C}$. Now they could see that those who had not made a best-fit graph had not relied on accepted knowledge. So how do people know 
that points on a graph formed a pre-determined pattern? What's more John then drew their attention to biological measurements, e.g. of heart rate, which didn't have a best fit. All their certainties were beginning to collapse but at the same time they became conscious that it was human beings like themselves who could infer patterns from data. Rather than a feeling of helplessness there was more a sense of emancipation, that the description of Nature was always provisional, that Nature didn't tell them just how it was, there is always interpretation.

Like Tom, John had refused to impose an answer. Providing a forum for discussion and expressing doubt had allowed the students to accept the problem of certainties, that uncertainty held promise, and that they were intimately connected to shaping their own understanding of Nature. John had no control of where the discussion would go although he had sufficient knowledge to make the grounds for the discussion coherent. It was a risk but one based on respecting what pupils would bring to the discussion, and a respect for the probabilistic account that respect for nature always gave.

\section{Towards a Transformation}

One response to the STEM hegemony is to emphasize the links between science and education and activism (Hodson, 2010; Bencze \& Carter 2011), an approach to which I am sympathetic. I have written about how closely the scientific principles of the production of materials for a consumer society are interwoven with the economic ruthlessness which provides cheap goods for the market at the expense of those, unseen and marginalised, who source the raw materials for processing (Levinson, 2014). Activist approaches, however, risk buttressing the rationale for STEM because they are the other side of the instrumental coin. Corporate capitalism is adroit at playing this game because it appropriates resistance to its own advantage (Bauman, 2000). The image of Che Guevara has become commodified into street chic. Coca-Cola, using green iconography, advertise green recyclable bottles to show how much they care for the environment (Balch, 2011), dreamed up, no doubt, by their global head of sustainable packaging (a post in Coca-Cola - it would be impossible to make it up).

I am cautious about aims that counter STEM by stipulating social justice because they risk reproducing the same instrumentality on which STEM thrives. Justice and openness to Nature and the Other has to be core to science pedagogy, not only an aspiration. This is not easy to attain when working in an environment so hostile to such practise. Teachers, whether pre-service or experienced, cannot ignore examination teaching, refuse to teach the set curriculum, or carry out day-to-day duties. They cannot simply opt out of school politics; indeed it would militate against the meaning of justice and acceptance of the other to do so.

One criticism of acceptance of the Other presupposes toleration of views which are antipathetic to human and non-human respect: racism, sexism, homophobia, colonialism. But this move anticipates a commitment to understanding and critiquing those material factors on which these views thrive. To act in this way is, for example, to take the racist off-guard. It also implies consistent inquiry into motivations and uncovering sources of power, which obstruct praxis. But there are far more everyday aspects with which 
teachers struggle, e.g., disruptive behaviour - truancy, lack of resources, bullying, which can test the best of intentions in classroom practise.

Marilyn Cochran-Smith (1991) describes a strategy of "collaborative resonance", an opening up of democratic spaces, where pre-service teachers work with more experienced teachers and educationalists whose own practise resists dehumanisation of the school system. Through collaboration, discussing problems and critique, a process of inquiry is made possible which allows a constant reflection on the theory-practice continuum and to problematise their own practice through their social, professional and political contexts. The difficulty, however, is that the performative dominance of schools today is greater than it was 25 years ago, and there are precious few spaces where preservice teachers can work within the relatively hospitable and encouraging environments that Cochran-Smith describes.

Nonetheless, the point about building on possibilities of resistance is a potentially promising one. In a research project funded by the British Academy - UK and Brazilian colleagues - explored the possibilities and challenges for science practitioners we identified as "teaching against the grain". The criteria for choice were those teachers who were known to us as mentors of pre-service teachers, with at least five years teaching experience, who were well-respected by their colleagues, took an active part in school and national science projects, were admired and loved by their students, and who were known to articulate and problematise issues of social justice through their own practise. Through a narrative approach (Goodson, 2008) in which they were encouraged over a series of sessions to tell the story of their professional development, the stories of the UK teachers demonstrated how recent managerial innovations in schools had conflicted with their own practise. Of the four UK teachers we worked with, two had since left teaching because they felt alienated by developments in their own school, which conflicted with their sense of communality and pedagogy. One was still teaching in his own inspiring way but was marginalised from effective organisational control.

The fourth teacher, Don, with twenty years experience, not only was still teaching but was gradually finding ways of influencing national professional bodies. He worked in an inner city school, multi-ethnic, drawing mainly from areas of high social deprivation. Don was fortunate in working in an institution that historically allowed teachers considerable autonomy but also encouraged professional collaboration and pursuance of higher academic qualifications:

There were all kinds of freedoms. There was the freedom to develop the kind of curriculum which suits the kids, and I think that was the culture of the place, that whole structure of team meetings, what you were going to teach anybody and being involved in the staff meetings where clearly decisions were made to some degree. There seemed to be a structure not only over which you had control and also responsibility. For the curriculum you felt responsibility as well. Yes, there was that. But also the other freedom you've got was, and what I was involved in was the freedom to get involved outside . . . and at the same time I'm reading quite a lot of philosophy and so through the history of science I'm coming across a lot of people like Foucault and really sort of disturbing my philosophical outlook and I'm involved in Marxist politics so that's also 
having an influence ... Theories of knowledge. So I think probably always looking for a secure foundation for what I'm doing. Probably not finding it . . . (laughter). But you know clearly not comfortable with merely a pragmatic approach.

Don's pedagogy was based on telling stories from within, to encourage students to experience what it was like to encounter new and unexplained scientific phenomena:

... upfronting the Aristotelian approach and then contrasting that with Galileo's views of motion, say. It's still a method which is used in physics teaching and so having read Aristotle and Galileo it helps. I did have a notion which perhaps grew out of the primary school teaching about narrative and telling stories and that being useful, not only in teaching young people, but teaching, actually having a story to tell helped people relate to the conceptual material that was underlying what you were trying to teach, and also gave it a form. And at the time in the history of science in the early modern period I was studying Latin... and as part of the course I decided to do a summer school in ancient Greek and we studied the Odyssey and the Iliad and I got interested in how those epic poems were designed and so they got a structure and...the beginning and the end reflect each other... and I sort of formed the notion about lesson planning and long term planning based on the structures of poetry.... And if you give this kind of structure to your lessons and your year it may helps both you and the kids or the adults to put a pattern to the learning. And so I'm borrowing from everything that's coming at me.

His problem was not the institution, which encouraged creative disturbance, but the reactions of his students who wanted to know how his pedagogic philosophy would help them pass their examinations. They were seemingly uncurious about how they could explain the world but more concerned with being able to produce the right answers to help them get their university places:

...particularly young people who really are increasingly instrumental about these two or three years of education...getting them through that and...their examination results which are going to get them on to the next stage and change their lives... and coming from backgrounds where they come from, workless households, this is useful, and so the degree to which you're treating it other than a body of knowledge which you need to get to grips with has to be tempered with the need to get them through the examinations... increasingly being pulled into that, isn't the most efficient method of getting through. So there are a number of tensions creeping in particularly when you become aware of them... which is when they start asking you what's in the exam.

And his approach to this problem of focus only on the examination results leads to negotiation: 
So the notion about being explicit...about why I'm taking this approach and so...I think certainly in the past few years I've been really clear with kids about talking to them about why it is I'm teaching them the way I'm teaching them and engaging them with that. I try not to burden them. I find that quite helpful.

Don's solution to the problem is to explain his pedagogy to the students, so they come to trust his judgement. The refusal to submit only to teaching to the examination is combined with a willingness to be open with the students, to expose his thinking to their consideration, so that authority for learning is shared. Like Tom and John he refuses to impose his own knowledge but to trust to the students' judgment and their realisation that they are involved together in the project of learning and making sense of the world. Rejection is always a possibility but one which is based on openness and trust.

\section{Conclusion}

If those concerned by STEM wait on national and international political changes, we are likely to have to wait for a long time. But change can be encouraged from bottom-up as well as top-down., particularly through collaboration, problematisation and shared goals. The point about Don's practise, like those of John and Tom, is that his pedagogy reflects a democratic and collaborative approach. In the performative world, risk and the possibility of failure, cannot be endured but the debate can be opened up and is always sensitive to the contexts of practise. The teaching that stimulates transformative approaches holds a tension between the Said - knowledgeable teaching - and the Saying, that which is open to the Other. The most appropriate term for this seems to be knowledgeability - openness to change is encouraged by those whose knowledge of their subject is non-presumptive and built upon a notion of social justice at the very core of teaching.

\section{REFERENCES}

Adams, R. (2013, December 03). UK students stuck in educational doldrums, OECD study finds. The Guardian. Retrieved [19 ${ }^{\text {th }}$ July, 2016], from https://www.theguardian.com/education/2013/dec/03/uk-students-education-oecd-pisareport

Arendt, H. (1998). The human condition. Chicago \& London: University of Chicago Press.

Balch, O. (2011). Coca-Cola in green bottles. The Guardian. Retrieved [1 $1^{\text {st }}$ October, 2016], from http://www.theguardian.com/sustainable-business/coca-cola-green-plant-bottles

Ball, S. J. (2003). The teacher's soul and the terrors of performativity. Journal of Education Policy, $18(2), 215-228$

Bauman, Z. (2000). Liquid modernity. London: Polity.

Bencze, L., \& Carter, L. (2011). Globalizing students acting for the common good. Journal of Research in Science Teaching. 48(6), 648-669.

Bernal, J. D. (1969).Science in history. London: Penguin.

Blades, D. W. (2006) Levinas and an ethics for science education. Educational Philosophy and Theory, 38(5), 647-664.

Caprile, M., Palmén, R., Sanz, P. \& Dente, G. (2015). Encouraging STEM studies for the labour market. Brussels: European Union. Retrieved from http://www.europarl.europa.eu/RegData/etudes/STUD/2015/542199/IPOL_STU(2015)54 2199_EN.pdf

Chinnery, A. (2000). Levinas and ethical agency: toward a reconsideration of moral education. Philosophy of Education, 2000, 67-74.

Cochrane-Smith, M. (1991). Learning to teach against the grain. Harvard Educational Review, 61(3), 279-310.

Dominiczak, P. (2013, July 08). Michael Gove: New curriculum will allow my children to compete with the very best. The Telegraph. Retrieved $\left[6^{\text {th }}\right.$ November, 2016, from http://www.telegraph.co.uk/education/educationnews/10166020/Michael-Gove-newcurriculum-will-allow-my-children-to-compete-with-the-very-best.html. 
Hodson, D. (2010): Science Education as a Call to Action, Canadian Journal ofScience,

Mathematics and Technology Education, 10(3), 197-206.

Hutchinson, J. (2012). Career-related learning and science education: the changing landscape. School Science Review, 94(346), 91-97.

Kermode, F., \& Richardson, J. (Eds.). (1997). Wallace Stevens: Collected poetry and prose. New York: Library of America.

Kind, P. M., \& Kind, V. (2007). Creativity in science education: perspectives and challenges for developing school science. Studies in Science Education, 43(1), 1-37.

Kuhn, T. (1970). The structure of scientific revolutions. Chicago, London: University of Chicago Press.

Layton, D. (1973). Science for the people. London: Allen \& Unwin.

Levinas, E. (1993). Outside the Subject, M. B. Smith, trans. London: Athlone Press.

Levinson, R. (2014). Undermining neo-liberal orthodoxies in school science: telling the story of aluminium. In L. Bencze \& S. Alsop (Eds.), Activist science and technology education (pp. 381-3880. Dordrecht: Springer. Llewelyn, J. (1991). The middle voice of ecological conscience. London: Macmillan.

Mayer, R. (1989). Cognitive views of creativity: creative teaching for creative learning. Contemporary Educational Psychology, 14, 203-211.

McCarthy, T.A. (1978). The critical theory of Jürgen Habermas. Massachusetts Institute of Technology.

Osborne, J. \& Dillon, J. (2008). Science Education in Europe: Critical reflections. King's College, London.

Owen, R., MacNaughten, P. \& Stilgoe, J. (2009). Responsible research and innovation: From science in society to science for society, with society. Science and Public Policy, 39, 751-760.

Rorty, R. (1989). Contingency, irony and solidarity. Cambridge: Cambridge University Press.

Rose, S. (1998). Lifelines: biology, freedom, determinism. London: Penguin.

Schreiner, C., \& Sjøberg, S. (2007). Science education and youth's identity construction: Two incompatible projects? In D. Corrigan, J. Dillon, \& R. Gunstone (Eds.), The reemergence of values in science education (pp. 231-248). Rotterdam/Taipei: Sense.

Strike, K.A., \& Posner, G.J. (1982). Conceptual change and science teaching. European Journal of Science Education, 4(3), 231-240.

The Royal Society. (2009). Hidden wealth: the contribution of science to service sector innovation. London: The Royal Society.

Tobin, K. (2014). Using collaborative inquiry to better understand teaching and learning. In L. Bencze \& S. Alsop (Eds.) Activist science and technology education (pp. 127-148). Dordrecht: Springer.

\section{AFFILIATIONS}

\section{Ralph Levinson}

UCL Institute of Education

University College London 